\title{
SUPPLY CHAIN RICE SEEDS AT MALANG REGENCY: SUPPLY CHAIN MACRO PROCESSES
}

\author{
Aulia Raharja $^{1, *}$, Budi Setiawan ${ }^{2}$, Rini Dwiastuti ${ }^{2}$ \\ ${ }^{1}$ Master's Degree, Post Graduation Program Faculty of Agricultural Economics, University of Brawijaya, \\ Indonesia \\ ${ }^{2}$ Departement of Socioeconomics Faculty of Agricultural Economics, University of Brawijaya, Indonesia \\ *Corresponding author: auliaraharja@ymail.com
}

\begin{abstract}
The aim of this research is to analyze the relationship performance between rice seed firms and partner famers I, partner famers I and partner famers-II, rice seed firms and farm stores, farm stores and farmers seed user in Malang Regency. The sampling method used is multistage sampling to determine rice seed firms, suppliers, and customers. Meanwhile, Data Envelopment Analysis (DEA) is used in this research with assumption of Constant Return to Scale (CRS) input oriented. Moreover, measurement value of interrelation based on a performance approach which is an efficiency aspect of each rice seed supply chain. Interrelation between rice seed firms and partner farmers-I synchronous at variable quality supplier selection, while partner farmers I and partner farmers-II have sufficient performance and the important variable is supplier integration. Other performance results are interrelation between rice seed firms and farm stores and the performance synchronous between farm stores and farmers' seed user has a high perception at variable customer service.
\end{abstract}

Keywords: supply chain macro processes, relationship performance, supplier relationship management, customer relationship management, rice seeds

\section{INTRODUCTION}

Seed is one of inputs for agricultural production that provides benefits in increasing crop productivity. One of the regencies used in rice seed production in East Java is Malang Regency which has the potential of rice seeding, the data which shows that in 2015 the largest level of rice plants was $69.52 \mathrm{qu} / \mathrm{Ha}$ and tenth largest production was 470,283 tons out of a total of 38 districts/city in East Java ((Dinas Pertanian Provinsi Jawa Timur, 2016). Based on these data, it will require some amount of seeds for quantity production in Malang Regency, so it needs to be integrated continuity of raw materials rice seeds.

To fulfill dry field rice must have good relationship between rice seed firms and farmers who have contracted in order to meet market needs and relationships with customers. Integrated planning, control and processes in supply structures provide superior values at minimum costs in the supply chain while still satisfying the desires of others in the supply chain (Vorst, 2001).

Seed conditions in Malang Regency are ways carried out by Anatan and Ellitan (2008) that Supply Chain Management is the concept of single competition to be network competition.
Furthermore, Indrajit and Djokopranoto (2002) have new developments, namely supply chain networks which are very optimal networks and are known as business partnering

The supply chain also includes all interactions between suppliers, producers, distributors and customers (Heizer and Render, 2005). It is applied to unite suppliers, entrepreneurs, warehouses and storage places efficiently, so that products can be produced and distributed with the right amount, the right location and the right time so that it can minimize costs and meet customer needs according to demand (Simchi-Levi, et al., 2000). The success of cooperation will be achieved through improving the performance of the company based on the conditions of good relationships with both partners.

Rice seedling in Malang Regency involves several cooperative relationships between supply chain actors, consisting of rice seed firms, partner farmers I, partner farmers II, farm stores and farmers seed user.

All processes in the supply chain can be categorized into three main areas: the process is focused downstream, internal and upstream and the classification is used to determine three supply chain macro processes including customer relationship management (CRM), internal supply 
chain management (ISCM) and relationship suppliers management (SRM) (Chopra and Meindl, 2007).

This research is interesting because in the previous study by Pasutham (2012) measuring supply chain performance in a macro process in three perspectives used in manufacturing companies. So there is no specific research to determine the supply chain conditions at a macro process in agricultural products, especially rice seeds.

An increasingly complex supply chain process will also increasingly require the efficiency of more critical information and material flows between organizations in the chain. Therefore, it is important to understand how to achieve successful cooperative relationships between the organizations involved in this matter will be measured by the level of perceived satisfaction in the relationships that exist (Jonsson \& Zineldin, 2003)

Therefore, it is necessary to do research to find out the overall supply chain management of rice seeds from upstream to downstream by applying the supply chain concept in a macro process to find out the relationships between the actors of rice seed supply chain in Malang Regency based on their performance from the perspective of Supplier Relationship Management (SRM), Internal Supply Chain Management (ISCM) and Customer Relationship Management (CRM).

\section{RESEARCH METHODS}

Research on rice seed supply chains was carried out in Malang Regency. Determination of sampling method is by multistage sampling to determine rice seed firms, suppliers and customers. Location determination is purposively based on the consideration of data of the Seed Trader Producers Association (HPPB), Malang Regency was one of the regions included in the top five producers that played an active role in the rice seed production system in East Java. In addition, data from Seed Overseeing and Certification Agency (BPSB) in Malang Regency there are four rice seed firms.

Respondents of partner farmers I were carried out using snowball sampling method backward linkage. Initial information was obtained through four rice seed firms who became key informants to find out the number of partner farmers I who were directly related to rice seed production activities, so that the total respondents of partner farmers were 19 respondents.

Respondents partner farmers II are farmers who establish direct cooperation with partner farmers I in producing rice seeds. Information on the number of partner farmers II is obtained from partner farmers I who come from members of farmer groups or individual farmers, totaling 43 respondents. Especially for respondents from members of the farmer group included in the partner farmers II, it is done by simple random method with proportional sampling. Whereas for individual farmer respondents conducted by census. So that the total respondents of the partner farmers, both partner farmers I and partner farmers II from all rice seed firms in this research were 62 respondents.

Farm stores respondents who obtained information from rice seed firmrs as key informants. Through this information, information was obtained regarding farm stores that collaborated with rice seed firms using the snowball sampling method forward linkage. There were eight farm stores that cooperated with rice seed firms at Malang Regency.

Determination of respondent farmers seed user using sampling method by accidental sampling because the total number of farmers who use seeds that buy rice seed products at the farm store is still unknown, so choose a sample that happened to be found in the farm store at that time with total ten farmers seed user.

In conducting interviews with questionnaires, researchers obtained data on the conditions of the supply chain of rice seeds through interrelation perceptions of performance between supply chain actors who formed cooperation. So from this data, intensive observation is needed regarding the performance of rice seed supply chain in the macro process as an illustration of rice seed supply chain management at Malang Regency.

This research is using Data Envelopment Analysis (DEA) approach which uses assumption of Constant Return to Scale (CRS) oriented input. In this research, measurement value of interrelation based on the performance approach is an efficiency aspect of each rice seed supply chain. DEA does not require a complete specification of the form of a function that shows the relationship of production and distribution of an observation, so that DEA is needed in managerial applications which have the ability to identify entity units that are used as references in helping to find causes and solutions inefficiency of a DMU (Fethi and Pasiouras, 2010).

In addition to obtaining relation values per variable in each supply chain actor, also obtained the results of the overall performance analysis of each supply chain interrelation so that it can produce a technical gap that compares the performance of the best relations, to produce a performance match between actors, among others (a) performance of rice seed firms to partner farmers I and otherwise (b) gap performance of partner farmers I to partner farmers II and otherwise, (c) gap performance of rice seed firms to farm stores and otherwise, (d) performance gap of farm stores to farmers user seed and otherwise. 


\section{RESULTS AND DISCUSSION}

Supplier relationship management (SRM) is is an approach to manage firms interaction with their suppliers. It is an improvement of customer relationship management (CRM) as a strategy to develop relationship between firms and their suppliers (Mettler and Rohner, 2009).

\section{Perceptions of Rice Seed Firms to Partner Farmers I}

The relationship between rice seed firms and partner farmers $\mathrm{I}$ is the relationship in providing and producing rice seeds. In the performance measurement per variable in Figure 1 it is found that the supplier selection variable has a fairly close relationship level of 0.825 compared to other variables.

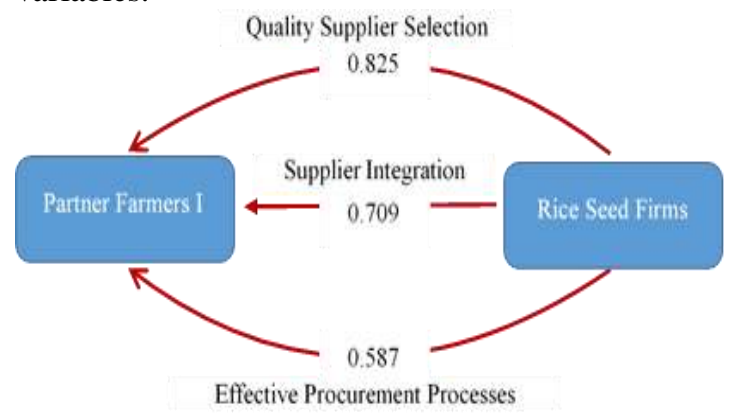

Figure 1. Relation Analysis per Variable Based on Performance of Rice Seed Firms to Partner Farmers I Rice Seed Commodity at Malang Regency

There are three factors measuring SRM. The performance in strategic level consists of quality supplier selection, supplier integration and effective procurement process. These three factors have their indicators.

There are several factors that influence supplier selection variables so that they get a fairly close relationship value, including supplier performance, selection process and green supplier.

Supplier performance is seen from the quality of rice seed products, delivery performance and storage quality. Supplier performance shows whether supplier can deliver raw materials on time and in good conditions (Chan, et al., 2003). Rice seed producers guarantee the purchase price of rice seeds that are higher than the market price, so that it affects partner farmers I to be able to provide quality production according to the standards of the Seed Overseeing and Certification Agency (BPSB) to rice seed producers.

The selection process is an activity carried out by rice seed firms in selecting partner farmers I partners to be able to cooperate with the requirements must have a high commitment and can maintain mutual trust in the relations that will be formed to achieve a common goal even though there is no written contract or formal document between the two sided.

While the green factor is known that partner farmers do not provide policies on environmental issues because it is still difficult to invite farmers to adopt new technology or better seed systems.

\section{Perceptions of Partner Farmers I to Rice Seed} Firms

Supplier selection factor has the largest relation value compared to other variables that is equal to 0.868 indicating that indicators of supplier performance measurement, selection process and green supplier are said to be quite close. Partner farmers I consider that these three indicators have a level of importance on the relationship with rice seed firms.

Partner farmers I in collaboration with rice seed firms are given a high sense of trust in producing rice seeds, in addition producers provide information on varieties grown according to market demand which makes the price of rice seeds produced quite profitable.

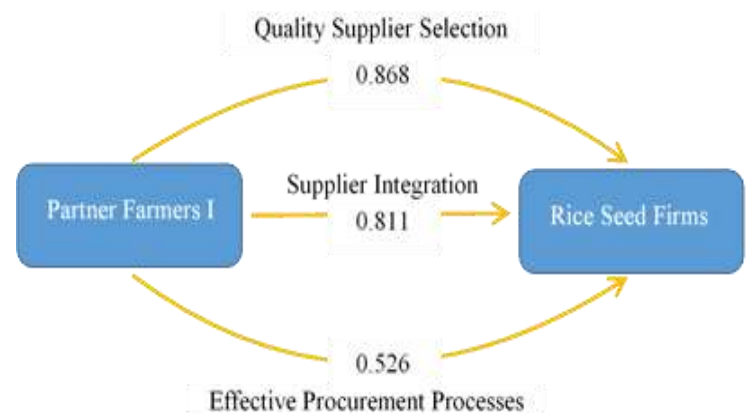

Figure 2. Relation Analysis per Variable Based on Performance of Partner Farmers I to Rice Seeds Firms at Malang Regency

Overall it can be concluded from the results of the analysis obtained in Table 1 that the perception of farmer partners who collaborate with producers provides an assessment that UD. VTMS and UD PJ have a close relationship with its partner farmers because the producer always facilitates and communicates every thing that happens in the production process so that the highest level of obtained relations among other producers.

Table 1. Relation Results Based on Performance of Partner Farmers I to Rice Seeds Firms at Malang Regency

\begin{tabular}{clc}
\hline \multicolumn{3}{c}{ Malang Regency } \\
No. & Rice Seed Firms & $\begin{array}{c}\text { Level of } \\
\text { Relation }\end{array}$ \\
\hline 1 & UD. VTMS & 1.000 \\
2 & PB. BAM & 0.456 \\
3 & PB. ST & 0.564 \\
4 & UD. PJ & 1.000 \\
\hline \multicolumn{3}{c}{ Average } \\
\hline
\end{tabular}

Sources: Primary Data, 2018 (Processed) 


\section{Perceptions of Partner Farmers I to Partner Farmers II}

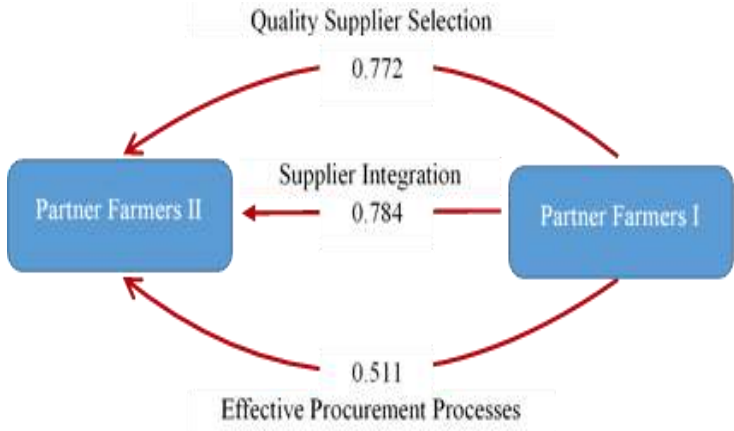

Figure 3. Relationship Analysis per Variable Based on Performance of Partner Farmers I to Partner Farmers II Rice Seed Commodities at Malang Regency

Supplier integration has a relation value based on its performance. That is close enough that is equal to 0.784 compared to other variables.

This variable variable consists of indicators of coordination, information integration, organizational relations and use of information technology Information integration explains how far all functions in delivering informations between firm and suppliers can effectively run (Chan, et al, 2003). It is quite tight because the field conditions state that partner farmers II are benefited by the decision of partner farmers I who are willing to share the risk in rice seed production activities by buying their products even though the quality is below the established criteria. In addition, providing information on routine production or coordination is more often done by face to face and using mobile phone media for urgent communication.

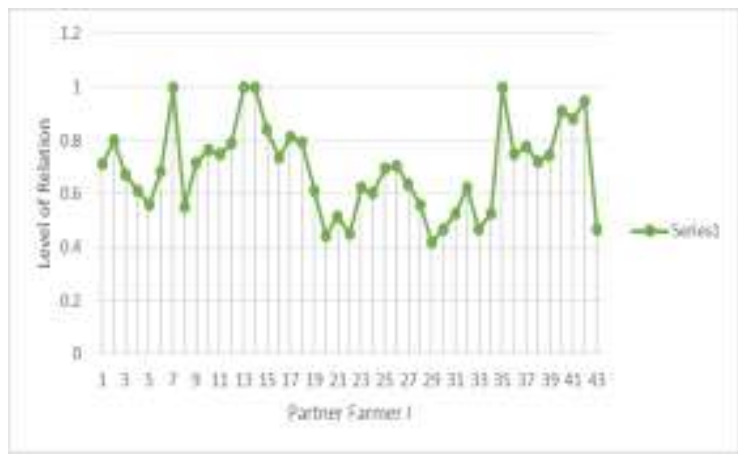

Figure 4. Graph of Relation Based on Performance of Partner Farmers I to Partner Farmers II Rice

Seed Commodities at Malang Regency.

Figure 4 describes the results of the best relations performance based on firm perceptions of partner farmers I indicating that three partner farmers I UD. VTMS and one partner farmers II
UD PJ have the maximum relation value that is equal to 1 so that it can be concluded that the four farmer partners have the best performance compared to other partner farmers so that a very close relationship exists between the two sided.

\section{Perceptions of Partner Farmers II to Partner Farmers I}

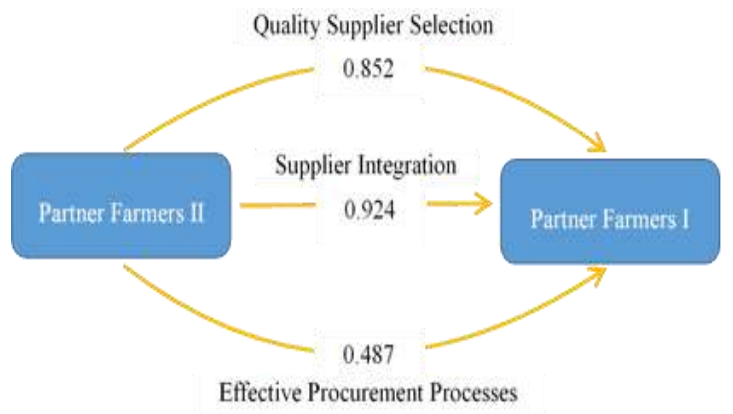

Figure 5. Relationship Analysis per Variable Based on Performance of Partner Farmers II To Partner

Farmers I Rice Seeds Commodity at Malang Regency.

The results of the analysis of partner level II farmer relations to level I partner farmers based on their performance have a relatively close value, except for the purchase effectiveness variable. The complete results of the relation are shown in Figure 5 .

Supplier integration has a fairly close value that is equal to 0.924 , this is because partner farmers I are willing to share risks in production activities while still buying production at lower prices if the quality produced does not meet the established criteria. This is inversely proportional to the relationship of firms who are not willing to share risk with partner farmers I.

Likewise, if there are cultivation problems that result in a decrease in production, then partner farmers I are willing to help deal with the problem by providing assistance to partner farmers II. From the positive number of perceptions that are given, indirectly this supplier integration variable has a closer value than other variables.

\section{Perception of Rice Seed Firms to Farm Stores}

The results of the analysis of the relationship of rice seed firms to farm stores based on their performance have a fairly close value on the variables of customer service and demand forecasting. The complete results of the relation are shown in Figure 6. 


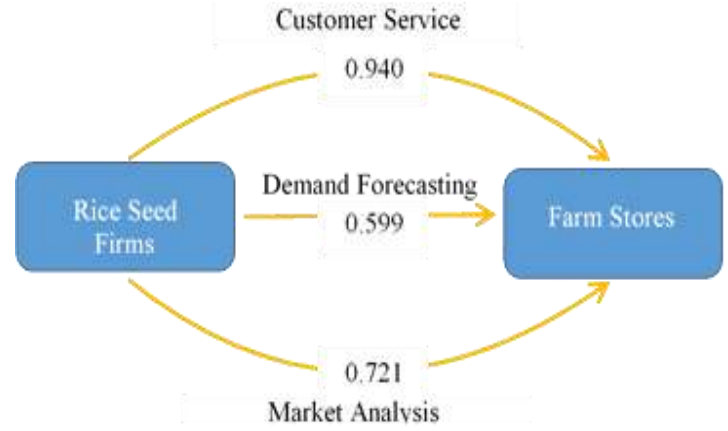

Figure 6. Relation Analysis per Variable Based on Performance of Rice Seed Firms to Farm Stores at Malang Regency

Consumer service has a relation value of 0.940 which can be said that there is a fairly close relationship based on the performance of two sided. It is because producers need farm stores as a place to market their products, as well as farm stores needing sales stocks in accordance with market demand, so that the existing cooperation must be increased for the benefit of marketing continuity. Rice seed firms provide seed stocks that match the needs of farm store with an average ordering cycle carried out three times a week.

Table 2 shows that the perception of firms who work with the best performing agricultural stores is UD PJ. So, good quality relationship with the farm shop must be maintained to get mutually beneficial marketing results and can increase the trust that has been established so far.

Table 2. Relation Results Based on Performance of Rice Seed Firms to Farm Stores at Malang Regency

\begin{tabular}{ccc}
\hline No. & Rice Seed Firms & Level of Relation \\
\hline 1 & UD. VTMS & 0.867 \\
2 & PB. BAM & 0.585 \\
3 & PB. ST & 0.551 \\
4 & UD. PJ & 1 \\
\hline & Average & 0.751 \\
\hline
\end{tabular}

Sources: Primary Data, 2018 (Processed)

The picture above shows the relationship between agricultural stores to rice seed firms based on customer service performance which has a value of 0.984 and can be said to have a fairly close relationship between the two sided.

There is only a factor of customer service in the perception of this relationship that can be analyzed; this is because other variables cannot be done by the shop regarding the forecasting of demand and market analysis of the condition of the rice seed producer.

Stores rely on product quality from rice seed firms to remain stable in maintaining the performance of their products. In addition, firms also send products according to store demand and with a fast delivery process. Rice seed firms guarantee the product, so the farm store does not need to worry if there is a complaint from the consumer.

\section{Perception of Farm Stores to Rice Seed Firms}

The picture above shows the relationship between agricultural stores to rice seed producers based on customer service performance which has a value of 0.984 and can be said to have a fairly close relationship between the two. There is only a factor of consumer service in the perception of this relationship that can be analyzed, this is because other variables cannot be done by the shop regarding the forecasting of demand and market analysis of the condition of the rice seed producer.

Stores rely on product quality from seed producers to remain stable in maintaining the performance of their products. In addition, producers also send products according to store demand and with a fast delivery process. Seed producers guarantee the product, so the store does not need to worry if there is a complaint from the consumer.

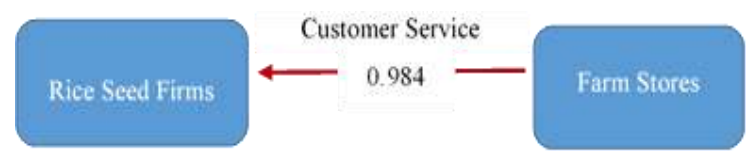

Figure 7. Relationship Analysis per Variable Based on Performance Farm Stores to Rice Seed Firms at Malang Regency

Perception of Farm Stores to Farmers Seed User Consumer service has a relation value of 0.868 which can be said that there is a close relationship between the two parties. The farm stores implements a friendly service strategy to the farmers who buy rice seed products, with this treatment will make farmers loyal to the store. Purchases are made directly in the store because the shop has not made sales online, for farmers who use rice seeds come from the area around the store.

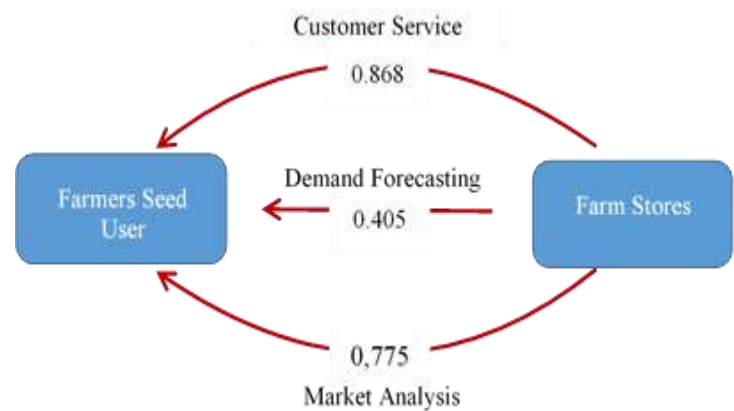

Figure 8. Relationship Analysis per Variable Based on Performance of Farm Stores to Farmers Seed User at Malang Regency

Table 3 shows the results of the farm stores relation to the farmer who buys the product from 
each rice seed firms, it is known that UD. VTMS and UD. PJ has a close relationship or has the best performance in products marketed to consumers through farm stores that work with rice seed firms.

Table 3. Relation Results Based on Performance of Farm Stores to Farmers Seed User at Malang Regency

\begin{tabular}{ccc}
\hline No. & Rice Seed Firms & Level of Relation \\
\hline 1 & UD. VTMS & 1 \\
2 & PB. BAM & 0.415 \\
3 & PB. ST & 0.418 \\
4 & UD. PJ & 1 \\
\hline & Average & 0.708 \\
\hline
\end{tabular}

Sources: Primary Data, 2018 (Processed)

\section{Perceptions Farmers Seed User to Farm Stores}

Figure 9 shows the relationship between farmers seed user to agricultural shops based on their performance has a value of 0.622 in the factor of customer service so that the relationship can be said to be not close between the two parties. There is only one factor that can be analyzed, this is because other variables cannot be done by consumers regarding demand forecasting and market analysts.

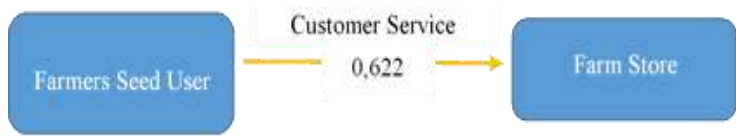

Figure 9. Relationship Analysis Based on Performance of Farmers Seed User to Farm Stores at Malang Regency

It is known that the store sells various types of agricultural products including the variety of rice seed products offered to consumers. Customers around the store make purchases directly at the store and get a after-sale guarantee if the purchased rice seeds cannot grow.

\section{Supply Chain Relation of Rice Seeds at Malang Regency}

Figure 10 it can be seen that the relationship between rice seed firms to partner farmers I interrelation performance between producers and partner farmers I can be concluded that between these actors have synchronous performance on supplier selection variables and supplier integration is a variable that has sufficient closeness and have more interest in supporting cooperative relations between the two parties.

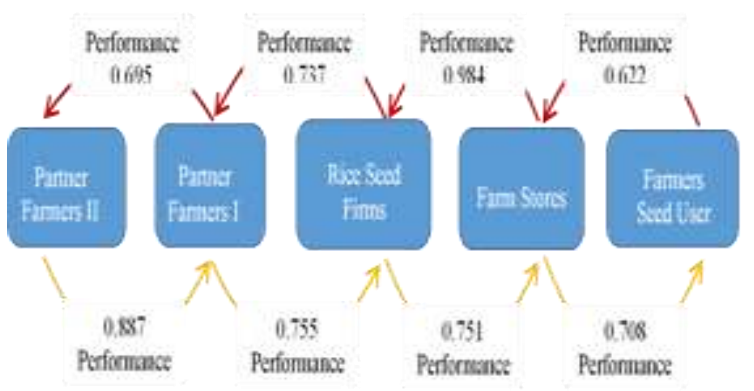

Figure 1. Relationship Analysis Based on Performance of Each Supplier of Rice Seed Chain in Malang Regency

The value of the relationship based on the performance of the partner farmers I and partner farmers I can be concluded that the relations between the two parties have a fairly synchronous performance because of the slight difference in perceptions of the variables namely the effectiveness of the purchase.

The value of relations between rice seed firms and farm stores based on their performance shows that rice seed firms and stores have quite synchronous performance because they lack interest in demand forecasting variables.

The results of farm shop relationships and user farmers based on their performance have synchronous performance because there is a suitability of perceptions on consumer service variables.

\section{CONCLUSION}

The conclusion that can be drawn from rice seed supply chain research in Malang Regency is as follows:

1. Interrelation performance between rice seed firms and partner farmers $I$ is said to have synchronous performance with more considered variables, namely supplier selection and supplier integration.

2. Interrelation performance between partner farmers I and partner farmers II has a fairly synchronous performance with less considered variables, namely the effectiveness of purchases.

3. The performance of interrelation between rice seed firms and farm stores has a fairly synchronous performance with less considered variables, namely demand forecasting.

4. Interrelation performance between farm stores and farmers seed user has synchronous performance with more considered variables, namely customer service. 


\section{REFERENCES}

Anatan, L. dan Ellitan, L., 2008. Supply Chain Management: Teori dan Aplikasi. Bandung: CV. Alfabeta

Chan, F.T.S., Qi, H.J.(2003). An Innovative Performance Measurement Method for Supply Chain Management. Supply Chain Management: An International Journal. Vol 8: 209-223

Chopra, S. dan Meindl, P., 2001. Supply Chain Management: Strategy, Planning and Operation. 2nd ed. New Jersey: Prentice Hall.

Dinas Pertanian Provinsi Jawa Timur, 2016. Evaluasi Kinerja Pembangunan Tanaman Pangan dan Hortikultura Jawa Timur, Surabaya: Dinas Pertanian Provinsi Jawa Timur.

Fethi, M. D. dan Pasiouras, F., 2010. Assesing Bank Efficiency and Performance with Operational Research and Artificial Intelligence Techniques. European journal of Operational research, Volume 204, pp. 189198.

Heizer, J. dan Render, B., 2005. Operation Management. 7th ed. New Jersey: Prentice Hall.
Indrajit, R. E. dan Djokopranoto, R., 2002. Konsep Manajemen Supply Chain. Jakarta: PT. Gramedia Widiasarana Indonesia.

Jonsson, P. dan Zineldin, M., 2003. Achieving High Satisfaction in Supplier Dealer Working Relationships. Supply Chain Management An International Journal, 8(3), pp. 224-240.

Mettler, T, Rohner P. (2009). Supplier Relationship Management: A Case Study in the Context of Health Care. Journal of Theoretical and Applied Electronic Commerce Research. Volume 4: 58-71

Pasutham, A., 2012. Supply Chain Performance Measurement Framework: Case Studies of Thai Manufactures. Thailand: Aston University

Simchi-Levi, D., Kaminsky, P., Simchi-Levi, E. dan Shanker, R., 2000. Designing and Managing the Supply Chain: Concepts, Strategies and Case Studies. Singapore: Mc Graw Hill Education.

Vorst, J. V. D., 2001. Enviromental Supply Chain Management: Using Life Cycle Assesment to Structure Supply Chains. The International Food and Agribusiness Management Review, 4(4), pp. 399-412. 